\title{
The Study of Social-Ethical Implications in Molana Quatrains
}

\author{
Dr. Hossein Behzadi Andouhjerdi \\ The associate professor of Persian language and literature group, Islamic Azad University, Tehran Central Branch \\ Hojjatollah Raisi \\ Student of PhD, Persian language and literature, Islamic Azad University, Tehran Central Branch
}

\section{Doi:10.5901/mjss.2016.v7n3s3p55}

\begin{abstract}
Jalaludin Bahauddin Soltane Olama Valad Ibne Hossein Ibne Ahmad Khatibi known as Molana is the creator of great works in prose and poetry in Persian literature; one of these works is Kullyat of Shams Tabrizi that includes his collection of quatrains that is known as a great extensive work and notable from different aspects same as poetic music and poetic expression, linguistic features, words variety, literary criticism, mystical thoughts, social and moral ideas, storytelling method and .... Study regarding this senseful and profitable work has not been investigated despite the availability of the other great works of Molana as Masnavi and Ghazalyat e Shams and the opportunity to work in this field is so wide and spacious. whereas, the root of each literary work develops in the social environment and the social requirements of a period is obvious in the poems of a poet and regarding the mastery of Molana on all the sciences in that time and his companionship with the people that lead to identification of social life experiences and moral contents in those days; so the present study investigates the social-moral contents of quatrains of Molana and it is hoped that it could serves to sociology studies of literature and sociological criticism and a starting point with the aim of comprehensive study of quatrains of Molana.
\end{abstract}

Keywords: Molavi, Quatrains, moral-social contents.

\section{Introduction}

The literary criticism also known as elocution and oration refer to "recognition of the value and the worth of literary works and scholium of it; so that the good and bad aspects and origin of it turn out to be known" (Zarrinkoob, 2002, p.2). The study of ethical and social issues that are considered as a kind of educational issues is a specific kind of criticism that is considerable regarding the study of didactic aspects of those works. There are many independent works in Persian literature that are considered in the field of educational literature that was written from the beginning with the aim of didactic and ethic. The works of Molana are full of ethical-social remarks. The Molana's quatrains that are considered in the present study are less addressed in literature due the great reputation of other works of Molana.

\section{Joy and Relaxation}

Achieving the joy, relaxation and comfort has been one of the desires of humans in all periods of history and different people with different thoughts have presented various viewpoints to achieve it. The joy is a belief by which the individual achieves to considerable issues and enjoyable emotions related to this belief $(A, 513,2005)$. Different political, social and economical factors contribute to create this feeling that meanwhile the role of the moral virtues is of great importance. It has been said regarding the relationship of moral virtues and the joy that "happiness is associated with the perfection and perfection requires the virtue. The virtue enables the person to gain the goodness required for joy. The virtue could be described as the moderated excitement by the wisdom. The virtue of the continence allows the person to moderate the enjoyment; so that could emphasize on the real goodness instead of apparent goodness considering the future of the action. Bravery enables the person to endure the pain and discomfort at the moment to make a better future" (Franklin, 2011, 148-149). "The individuals with positive temper are happier and participate in more activities, have less cautious manner and agree with others requests" (Argyle, 2007, 328). "The importance of social ethics has been added also in the modern societies and the human race will be disappearing in the case of disrespect to its regulations. Individuality and personal freedom have been preferred in the past few decades; But if this preference is not fitted in a social context, it could make the joyful life ineffective and even stopped" (Elis, 2005, 9-10). The contentment is one of the ethical virtues 
that have an effective role in this subject. Contentment refers to "self consciousness on the limit of paucity and sufficiency and cutting the cupidity from the desire of exuberance and excess. Every soul that has been endowed with this manner and characterized by such people, gains the benefit of the world and hereafter and the wealth of richness and leisure" (Kashani, 1988, 350). Contented people are satisfied with his assets and because he does not seek the superfluity, reach to joy and relaxation. Molana following the Shams is one of the happiness-oriented poets that believe that there are many ways to reach for joy; even the death that is a factor of grief and sorrow in other's view is joyous. Molana believes that one way to reach this feeling is that the man be satisfied with his half bread and be neither the seeker nor the sough of anyone. In his opinion, such an individual is qualified for living happily:

"Someone who goes with half a loaf of bread

to a small place that fits like a nest around him,

someone who wants no more, who's not himself

longed for by anyone else,

He is a letter to everyone. You open it.

It says, Live."

Molana states in criticize of the people of the time that "there are many happy or sad people, but they don't know what is the origin of this happiness or sadness"

"One nation is sad and they don't know its origin

One nation is happy and don't know that it is from God"

Other poets also have attended to the importance of contentment to make the people happy. Rudaki also suggests to his audience to live with contentment, don't look at the life of better people to avoid worrisome. Because the joy is in looking to the life of people at lower levels:

"Content with the given and live with justice,

Don't be imprisoned by troubles and live freely

Don't look at the better ones and don't worry,

Look at the lower ones and live happily"

Naser Khosro also considers the contentment as a factor of happiness and sees the contentment better that begging from ignoble persons for meeting the needs:

"I'm not disabled and powerless in my work,

All the people confess my virtue

But patience is more pleasant in the time of hunger than getting food from ignoble persons"

Saib Tabrizi considers the contentment as a sugar plantation that has no bitterness:

"There is no bitterness in the sugar plantation of contentment,

The view of ant is sugar in this desert"

Another way to reach the joy and happiness in theosophy is to release the worldly desires, "Abū-Sa'îd Abul-Khayr believes that the human heart should become empty from all the desires and wishes to reach the joy and relaxation" (Maier, 2008, 162). Molana believes that one of the ways to relaxation is that the human doesn't care for the wealth and assets. When the human doesn't care for wealth or for the humility, will reach to a status that make no difference between the gold and the stone. This is the status in which the man reaches to real relaxation and wealth or poverty could not make him happy or sad:

"A relieved person is the one that doesn't care for less or more,

The one that doesn't care for wealth or poverty

He is free from the sorrow of the world and the people,

He has no kinship with himself"

Molana looks at the subject of the world wealth from another viewpoint in another quatrain. He speaks about a slave or a beloved one that went to him because of gold and money. But when finds that there is no gold and money, doesn't adhere to the promise and leave. Molana concludes from this action that the slaves and servants keep their promise only in the case of wealth:

"Came to me since he thought of gold,

When found that there is no gold, forgot the loyalty

I think from the ring in his ear that where there is gold, it should be an ear to listen"

\section{Hardness and Comfort}

Molana believes that in order that some people feel comfortable, some others should suffer hardship and their suffer 
result in comfort of others. He exemplifies his thought for making them tangible. One example is that the tears of the clouds (personification) cause the growing of plants and trees. Another example is addressed to parents; the result of their difficulty is in the comfort of their children:

"The fortune is bitter and the clouds are wet,

These tears is for the sake of laughter of plants and trees

The play and joy of children is from the cry of mother and the restraints of the father"

\section{Conclusion}

One of the considerable points in Molana's quatrains is social-ethical issues. He considers the feelings of sorrow and joy and knows the most important way to reach the joy in contentment to assets and leaving the cupidity. He invites the individuals to the recognition of self and his status and considers the comparison of their lives to others as the source of sorrow and sadness. He also has a positive view toward the death, because the man could reach the God through death. Molana believes that the difficulties are the requirements of growth and comfort and these two factors going on together.

\section{References}

Argyle, Michael (2001), "Psychology of Happiness", translated by Masoud Gohari Anaraki and Hassan Palahang, Hamid Taher Neshat Doost, Masoud Gohari Anaraki and Fatemeh Bahrami, (2004), Jahad Daneshgahi.

Albert Ellis, Becker Irving (2005), "Personal Happiness", translated by Mehrdad Firoozbakht \& Vahide Mardani, Rasa Publication, Tehran.

Robert E. Franken (2005), "Motivation \& Excitement", Translated by Hasan Shams, First Edition, Tehran, Ney Publication.

Rudaki, J. (2000), "Diwan Rudaki". Ed. KHatib Rahbar, 19th Edition, Tehran, Safi Alishah Publications.

Abdolhossein, Zarinkoob, The value of Safavi heritage, $11^{\text {th }}$ Edition, Tehran, Amirkabir publication.

Saeb, Mirza Mohammad ali (1994) "Kolliat Diwan", Ed. by Amiri Firoozkoohi, 1'st Edition, Tehran, Khayyam Publication.

Samuel S Franklin (2011), "Psychology of Happiness", Translated by Jafar Najafi Zand, 1'st Edition, Tehran, Sokhan Publication.

Kashani, Ezz ol-Din Mahmoud, (1387). Mesbah al-Hedayah and Meftah al-Kefayah, corrected by Jallaledin Homaei, 1st Edition, Tehran, Sokhan Publications.

Meier, Fritz (2008), "Fact and the Myth", translated into Persian by Mehr-Afagh Baiboverdi. 1'st Edition, Tehran, University Publication Center.

Molavi, Jallaledin Mohammad (1992), "Kolliat Diwan-e-e Shams Tabrizi", Poetical work by Mansour Moshfegh (Ed.), 10th Edition, Tehran: Safi Alishah.

Naser Khosro (2003), "Diwan-e- Ashar". Corrected by Mojtaba Minavi \& Mehdi Mohaghegh, Third Edition, Tehran, Tehran University Publication. 